\title{
The Public and Public Relations: Examining their nexus in environmental pollution, laws, and policies of government
}

\author{
Oscar Odiboh ${ }^{1 *}$, Tayo George ${ }^{2}$, Odunayo Salau ${ }^{3}$, Thelma Ekanem ${ }^{1}$, Darlynton Yartey ${ }^{1}$, \\ Mercy Banda $^{1}$ \\ ${ }^{1}$ Department of Mass Communication, Covenant University, Ota, Ogun State, Nigeria \\ ${ }^{2}$ Department of Sociology, Covenant University, Ota, Ogun State, Nigeria \\ ${ }^{3}$ Department of Business Management, Covenant University, Ota, Ogun State, Nigeria
}

\begin{abstract}
Goals 6, 13, 14, and 15 of the United Nation's Sustainable Development Goals (SDGs) share global concerns of making the earth cleaner for human habitation. In Nigeria, pollution thrives despite the government's laws and policies. In the country, opinions on public issues are strong, and public relations (PR) professionals are perceived moulders of societal viewpoints. This study examines the connection between public awareness and PR actions on the sociological problems of environmental pollution, laws, and government policies in an industrial cum residential community in Southwest Nigeria. Based on the Environmental Communication Theory, which espouses nature-human environmental connectivity, this study adopts a quantitative, non-experimental, and descriptive methodology. Probability and non-probability sampling design and multi-stage techniques are applied to select 400 residents of Ota community. Scientific Package for Social Sciences (SPSS) is used to process 358 successful copies of the questionnaire. Results show that public awareness of environmental pollution is high; but low on its laws and policies. The contributions of public relations practitioners are acknowledged, but the government's actions are unfamiliar. Meagre public concern for environmental laws and policies and weak motivation by PR practitioners and the government threaten the achievement of identified SDGs of the UN at the study's location.
\end{abstract}

\section{Introduction}

Public relations (PR) is an essential component of communication that strategically seeks to influence behaviour change on essential health, education, and the environment. This type of communication aims to transfer information about organizations' reputation, interests,

\footnotetext{
* Corresponding author: odion.odiboh@ covenantuniversity.edu.ng
} 
services to the communities within the area of reach $(2,20]$. It also focuses on achieving reciprocal actions for an organization and its internal and external publics. It is a mutual communication type between the organization and its target audience, opportuning valuecreation through relationships and existential understanding [3]. Public relations activities also highlight issues concerning citizens' shared values and interests.

Public awareness campaigns are activities planned to raise knowledge and motivate a positive attitude in the target audience within a stipulated timeframe $[8,9,10]$. It brings to light the social problems of a particular community and how to tackle them according to global standards. These programs help the audience unlearn and learn new ways of living through community engagement [6]. The aim is to establish an agreement, trustworthiness, and connectivity with the external audience to solicit their support [25]. Public relations agents conduct activities within the social, cultural, political thinking, and setting of the target community. Some of the activities range from scheduled environmental cleaning, public enlightenment campaigns, and digging boreholes. Others are the free distribution of dust masks and donations of waste bins.

Environmental protection is an essential issue that countries worldwide (including Nigeria) are striving to achieve. These efforts align with the Sustainable Development Goals (SGDs) goals 6, 13, 14, and 15. Goal 6 is about sustainable management of water and sanitation. Goal 13 focuses on ways against climate change, while Goal 14 seeks to protect and sustain the use of oceans, seas, and marine resources. Goal 15 discusses the preservation of forests, mountains, and deserts [29, 30]. It is outlined that based on scientific evidence, human activities were exacerbating climate change and other environmental degradation [24]. In this view, they called for a wholistic communication intervention that would help determine public awareness of environmental protection and climate change in general.

Several types of research [12, 13, 21, 22, 28, a 30] report that environmental pollution severely affects the natural world and human life. Air pollution was the main contributor to climate change. The report pointed out that there were many respiratory-related diseases that human being suffers from as a result of breathing contaminated air. The report speculated that reducing pollutants like carbon and methane would help reduce the rise in temperature projected for 2050 by about 0.4 to $0.5^{\circ} \mathrm{C}$.

Moreover, studies affirm the occurrence of noise, water, and land pollution in the Ota area, with air pollution being more prevalent due to industrial activities $[11,17,19,26]$. They also observed that public relation is vital for social engagements on environmental issues in Nigeria. It is, therefore, essential to find out community awareness levels about environmental matters. To this effect, this paper seeks to examine the impact of Public Relations Activities, Public Awareness, Attitude, Environment Pollution, Policies, and Laws in the Ota area of Ogun State, Nigeria.

The minute introduction of a foreign substance, whether liquid, solid, or gas, into an environment and harms the elements that dwell within that space can be referred to as pollution. The concept of pollution was reported as the introduction of substance or energy by man into the environs, which is dangerous to human health, ecological systems, damage to structures, or cause interference with the environment's use as a whole [4]. Simply put, pollution occurs when there is a significant release of dangerous materials into the atmosphere, which is likely to harm live organisms. These substances can be referred to as pollutants, and they appear in stable liquids, gases, or a mixture $[1,4,16,18]$.

It is one thing to create awareness of the need to protect the environment; it is another thing to create laws or policies that govern actions and ensure strict compliance. These laws are official rules, decisions, and actions vis-à-vis the environment's quality, natural resources, and ecological sustainability [7]. It is a complex and interlocking statutes system, common law, regulations, and policies that seek to protect the natural environment that may 
be impacted or endangered by human activities. Across both summations, the environment's protection is paramount, which further stresses the need for policies.

Nigerian environmental policies have been reflected in different legislations before and after independence, with some of them as Forestry Regulations 1943, The Water Resources Control Law 1963, Harmful Waste Degree of 1988, etc. [5]. Different states took the initiative after the Federation had instituted the policies [14, 23, 27].

Environmental communication theory comprises human-nature relations [15]. The theory asserts that information impacts on how humans perceive their immediate environment. Humans react to the information that they receive and form opinions based on the environment around them. It means that the public understands government messages on environmental pollution, laws, and policies is critical because it determines their behaviour. The government is encouraging environmental advocacy and bringing about pollution prevention reduction plan for a safer society by enacting these laws. Then again, government laws and policies could be overly prescriptive and hard to follow. As such, public relations activities such as community relations, media relations, sponsorship, and partnership with corporate organizations, trade fairs, exhibitions, sports, among others, could be promising avenues for government to employ when sending out these kinds of information. In other words, the messages should be packaged in ways that would encourage citizen participation in environmental management and protection.

Furthermore, the public's understanding of environmental pollution, laws, and policies is influenced by a belief system based on their exposure to environmental concerns, impacting their understanding and reception of such messages. Thus, the government needs to take into consideration cultural factors, education, media, interpersonal networks, reasoning patterns, sociocultural beliefs, and motivation when packaging their message.

\section{Method}

This study adopted a cross-sectional non-experimental research design. The quantitative approach, specifically, the questionnaire, was adopted to gather relevant data. The rationale for this is to allow for detailed descriptions and perspectives on the issues raised. This study was situated in Ota, a significant city in Ogun State- one of the five southwestern states in Nigeria. Due to urbanization and the growing influx of people, many pockets of informal settlements and slums have emerged in addition to few Government Residential Areas and other Middle Areas.

The study examined the role of Public relations on Ota residents' awareness of environmental laws and policy on pollution and waste management. Ota is the industrial hub of the Ado Odo-Ota Local Government Area (LGA) of Ogun State, Nigeria. Ota community is within the 16 wards in Ado Odo-Ota local government area (LGA), with an estimated population of 526,565 residents was covered for the study [22, 31, 32]. The massive presence of manufacturing industries and the rising human population that supply the labour for the industries partly explains the volume of waste generated in the area.

Based on the fact that the study intends to investigate participants from three different locations with varying features, both probability, and non-probability sampling designs were adopted. The sample selection process was through a multi-stage sampling technique. In the first stage, Ado-Odo Ota local government was purposively selected because it is the most industrialized and densely-populated semi-urban centre in Nigeria [22, 31, 32]. In the second stage, the study area, which comprises an Area Council, was stratified into three clusters encompassing an industrial suburb, middle residential area, and slum settlements. The justification for stratifying the area into clusters is for all desired characteristics of the study location to be accommodated. In the third and final stage, a simple random sampling technique was adopted to select respondents from the study location's three settlements. 
The Simple Random formula used in this study is the sample size (n) of the population $(\mathrm{f}<0.05\}$, factoring a $95 \%$ level of confidence $(\mathrm{z})$ based on the population size $(\mathrm{N})$. The maximum population variability is $\mathrm{p}=\mathrm{q}=0.5$, giving a $<5 \%$ sampling error produced by 400 respondents.

A semi-structured questionnaire was used to collect quantitative data on participants' information and their socio-demographics. The returned copies of the questionnaire were edited to check for and minimize errors. Copies of the questionnaire with incomplete information were discarded while completed ones were coded for analysis.

\section{Results and discussion}

Five (5) questions in Table 1 were used to compute the public's summary responses on environmental pollution, laws, and policies of the government. The groups were divided into three: those who do (Yes), those who don't (No), and those who are undecided (Not sure).

Table 1. Public awareness of environmental pollution, laws and policies of the government (Source:

The authors, 2020)

\begin{tabular}{|c|c|c|c|c|c|}
\hline & Questions & Yes & No & Not sure & Total \\
\hline \multirow{2}{*}{1} & \multirow{2}{*}{$\begin{array}{l}\text { Are you aware of public } \\
\text { relations? }\end{array}$} & 314 & 26 & 18 & 358 \\
\hline & & $87.70 \%$ & $7.30 \%$ & $5 \%$ & $100 \%$ \\
\hline \multirow{2}{*}{2} & \multirow{2}{*}{$\begin{array}{l}\text { Are you aware of pollution } \\
\text { in your environment? }\end{array}$} & 307 & 34 & 17 & 358 \\
\hline & & $85.70 \%$ & $9.50 \%$ & $4.80 \%$ & $100 \%$ \\
\hline \multirow{2}{*}{3} & \multirow{2}{*}{$\begin{array}{l}\text { Are you aware of any } \\
\text { environmental law or policy }\end{array}$} & 128 & 167 & 63 & 358 \\
\hline & & $35.70 \%$ & $46.70 \%$ & $17.60 \%$ & $100 \%$ \\
\hline \multicolumn{5}{|c|}{4 Which of the following would you consider as environmental pollution? } & \\
\hline $\mathrm{S} / \mathrm{N}$ & Items & Frequency & $\%$ & Rank & \\
\hline I & Garbage by the roadside & 114 & 31.8 & 1 & \\
\hline ii & Industrial smoke & 77 & 21.5 & 2 & \\
\hline iii & Garbage in waterways & 76 & 21.2 & 3 & \\
\hline iv & Noise in public places & 44 & 12.3 & 4 & \\
\hline $\mathrm{v}$ & $\begin{array}{l}\text { Throwing waste out of } \\
\text { moving vehicles }\end{array}$ & 25 & 7 & 5 & \\
\hline vi & None of the above & 16 & 4.5 & 6 & \\
\hline vii & All of the above & 6 & 1.7 & 7 & \\
\hline \multicolumn{2}{|c|}{ Total } & 358 & $100 \%$ & & \\
\hline \multicolumn{5}{|c|}{5 How often is the waste in and around your environment disposed? } & \\
\hline $\mathrm{S} / \mathrm{N}$ & Items & Frequency & $100 \%$ & Rank & \\
\hline I & Once a week & 123 & 34.4 & 1 & \\
\hline ii & Once a day & 63 & 17.6 & 2 & \\
\hline iii & Once a month & 60 & 16.8 & 3 & \\
\hline iv & Twice a month & 50 & 14 & 4 & \\
\hline
\end{tabular}




\begin{tabular}{|l|l|l|l|l|}
$\mathrm{v}$ & Not sure & 45 & 12.6 & 5 \\
\hline vi & Never & 17 & 4.7 & 6 \\
\hline Total & & 358 & $100 \%$ & \\
\hline
\end{tabular}

Table 1 shows that only 314 respondents or $87.7 \%$ agreed that they are aware of public relations, while 26 respondents or $7.3 \%$ disagreed, and only 18 or $5 \%$ were not sure of their awareness of public relations. Similarly, 307 respondents or $85.7 \%$ agreed that they are aware of pollution in their environment. In comparison, 34 respondents or $9.5 \%$ disagreed, and only 17 or $4.8 \%$ were not sure of their awareness of pollution in the communities. The table also indicated that only 128 respondents or $35.7 \%$ agreed that they are aware of environmental law or policy. In comparison, 167 respondents or $46.7 \%$ disagreed, and only 63 or $17.6 \%$ were not sure of the established environmental law or policy.

Table 1 also shows the understanding and perception of the public on environmental pollution. One hundred fourteen respondents or $31.8 \%$ viewed environmental pollution as garbage by the roadside, 77 respondents or $21.5 \%$ said industrial smoke, 76 respondents or $21.2 \%$ perceived it as garbage in waterways, 44 respondents or $12.3 \%$ sees environmental pollution as noise in public places, 25 respondents or $7 \%$ viewed it as throwing waste out of moving vehicles. In comparison, 16 respondents or $4.5 \%$ said none of the above, and only six respondents or $1.7 \%$ chose all of the above.

Another question in Table 1 emphasized how often the waste in and around the environment is disposed of. $34.4 \%$ or 123 respondents affirmed that the disposal is often done once in a week; 63 or $17.6 \%$ said once a day, 60 or $16.8 \%$ said once a month, 50 or $14 \%$ said twice a month, 45 or $12.6 \%$ said once a day as opposed to $4.7 \%$ representing 17 respondents who said never.

Table 2. Public assessment of public relations practitioners' contributions to environmental pollution, laws and policies of the government (Source: The authors, 2020)

\begin{tabular}{|c|c|c|c|c|}
\hline $\mathrm{S} / \mathrm{N}$ & How do you perceive public relations? & Frequency & $\%$ & Rank \\
\hline I & Dressing well & 105 & 29.3 & 1 \\
\hline ii & Giving out gifts & 82 & 22.9 & 2 \\
\hline iii & Talking about organisations & 62 & 17.3 & 3 \\
\hline iv & Receiving visitors & 30 & 8.4 & 4 \\
\hline $\mathrm{v}$ & Image-making & 28 & 7.8 & 5 \\
\hline vi & Making friends & 25 & 7 & 6 \\
\hline vii & Walking for life & 18 & 5 & 7 \\
\hline \multirow[t]{2}{*}{ viii } & None of the above & 8 & 2.2 & 8 \\
\hline & Total & 358 & $100 \%$ & \\
\hline \multicolumn{5}{|c|}{2 Which of the following public relations did you notice in your community? } \\
\hline 1 & Environmental cleaning & 121 & 33.8 & 1 \\
\hline 2 & Donation of waste bin & 60 & 16.8 & 2 \\
\hline 3 & Public enlightenment campaigns & 74 & 20.7 & 3 \\
\hline 4 & Free distribution of dust masks & 54 & 15.1 & 4 \\
\hline 5 & The building of waste collection centres & 29 & 8.1 & 5 \\
\hline 6 & Digging of boreholes & 11 & 3.1 & 6 \\
\hline
\end{tabular}




\begin{tabular}{|c|c|c|c|c|c|}
\hline 7 & None of the above & 9 & 2.5 & 7 & \\
\hline & & 358 & $100 \%$ & & \\
\hline & Environmental Laws and Policy & Yes & No & $\begin{array}{l}\text { Not } \\
\text { sure }\end{array}$ & Total \\
\hline \multirow[t]{2}{*}{ I } & $\begin{array}{l}\text { Do you think environmental } \\
\text { management should be a public } \\
\text { relations activity? }\end{array}$ & 298 & 26 & 34 & 358 \\
\hline & & $83.20 \%$ & $7.30 \%$ & $9.50 \%$ & $100.00 \%$ \\
\hline \multirow[t]{2}{*}{ ii } & $\begin{array}{l}\text { Do you think public relations people } \\
\text { should help inform the citizens about } \\
\text { environmental laws and policy? }\end{array}$ & 269 & 41 & 48 & 358 \\
\hline & & $75.20 \%$ & $11.40 \%$ & $13.40 \%$ & $100.00 \%$ \\
\hline \multirow[t]{2}{*}{ iii } & $\begin{array}{l}\text { Was your awareness of this law or } \\
\text { policy aided by public relations } \\
\text { activities? }\end{array}$ & 109 & 128 & 121 & 358 \\
\hline & & $30.40 \%$ & $35.80 \%$ & $33.80 \%$ & $100.00 \%$ \\
\hline
\end{tabular}

Table 2 shows the understanding and perception of public relations. One hundred five respondents or $29.3 \%$ viewed public relations as talking about organizations, 82 respondents or $22.9 \%$ said image-making, 62 respondents or $17.3 \%$ perceived it as none of the above, 30 respondents or $8.4 \%$ sees public relations as giving out gifts, 28 respondents or $7.8 \%$ viewed it as making friends, while others constituting 51 or $14.2 \%$ respondents see public relations as dressing well, receiving visitors, and walking for life.

The respondents were also asked to identify some of the public relations activities they observed in their communities. $33.8 \%$ or 121 respondents identified environmental cleaning, 60 or $16.8 \%$ opposed with none of the above, 74 or $20.7 \%$ affirmed that PR activities in their community focused on public enlightenment campaigns, 54 or $15.1 \%$ said donation of waste bin, 29 or $8.1 \%$ said digging of boreholes, while 11 or $3.1 \%$ chose free distribution of dust masks and only 9 or $2.5 \%$ said the building of waste collection centres. This implied that the community members are, to some extent, aware of the activities that PR professionals/practitioners engage in.

Three (3) questions in Table 2 were used to compute the summary response on environmental pollution, laws, and policies. The groups were divided into three: those who do (Yes), those who don't (No), and those who are undecided (Not sure). Table 2 also shows that only 298 respondents or $83.2 \%$ agreed that environmental management should be a public relations activity while 26 respondents or $7.3 \%$ disagreed; only 34 or $9.5 \%$ were unsure whether environmental management should be included in public relations activities. Moreover, the table also indicated that only 269 respondents or $75.2 \%$, agreed that public relations people should inform the citizens about environmental laws and policy. In comparison, 41 respondents or $11.4 \%$ disagreed, and only 48 or $13.4 \%$ were not sure of the statement. To conclude, the table also indicated that 109 respondents or $30.4 \%$ agreed that public relations activities aided awareness of this law or policy. In comparison, 128 respondents or $35.8 \%$ disagreed, and only 121 or $33.8 \%$ were not sure that public relations activities have contributed to the awareness of environmental law or policy.

Table 3: Public assessment of the government's PR activities on environmental pollution, laws and policies Source: The authors, 2020

\begin{tabular}{|l|l|l|l|l|l|}
\hline & Questions & Yes & No & Not sure & Total \\
\hline 1 & Are you aware of any Public Relations & 238 & 69 & 51 & 358 \\
\hline
\end{tabular}




\begin{tabular}{|l|l|l|l|l|l|}
\hline & activity in your community? & $66.5 \%$ & $19.3 \%$ & $14.2 \%$ & $(100 \%)$ \\
\hline 2 & $\begin{array}{l}\text { Are you aware of steps taken by } \\
\text { government officials to inform the people } \\
\text { about environment pollutions, laws and } \\
\text { policy }\end{array}$ & $38 \%$ & $37.1 \%$ & $24.9 \%$ & $(100 \%)$ \\
\hline
\end{tabular}

Two (2) questions in Table 3 were used to compute the summary response to the government's PR activities' public assessment on environmental pollution, laws, and policies. The groups were divided into three: those who do (Yes), those who don't (No), and those who are undecided (Not sure).

Table 3 shows that only 238 respondents or $66.5 \%$ agreed that they are aware of their community's public relations activity. In comparison, 69 respondents or $19.3 \%$ disagreed, and only 51 or $14.2 \%$ were not sure of their awareness of public relations activities. Additionally, the table also indicated that only 136 respondents or 38\%, agreed that they are aware of the steps taken by government officials to inform the people about environment pollutions, laws, and policy. In comparison, 133 respondents or $37.1 \%$ disagreed and only 89 or $24.9 \%$ were not sure of the established environmental law or policy.

Table 4: Public assessment of private organisations' PR activities on environmental pollution, laws and policies of the government (Source: The authors, 2020)

\begin{tabular}{|l|l|l|l|l|l|}
\hline & Questions & Yes & No & Not sure & Total \\
\hline 1 & $\begin{array}{l}\text { Is there any corporate organisation } \\
\text { helping your community with } \\
\text { environment management? }\end{array}$ & $\begin{array}{l}156 \\
43.6 \%\end{array}$ & $\begin{array}{l}105 \\
29.3 \%\end{array}$ & $\begin{array}{l}97 \\
27.1 \%\end{array}$ & $\begin{array}{l}358 \\
(100 \%)\end{array}$ \\
\hline 2 & $\begin{array}{l}\text { Are corporate organisations helping to } \\
\text { inform your community about } \\
\text { environmental laws and policy? }\end{array}$ & $39.4 \%$ & $31.6 \%$ & $29 \%$ & \begin{tabular}{l}
$(100 \%)$ \\
\hline
\end{tabular}
\end{tabular}

Table 4 shows that only 156 respondents or $43.6 \%$ agreed that they are aware of their community's public relations activity. In comparison, 105 respondents or $29.3 \%$ disagreed, and only 97 or $27.1 \%$ were not sure of their awareness of public relations activities. Additionally, the table also indicated that only 141 respondents or $39.4 \%$ agreed that corporate organizations help inform the community about environmental laws and policy. In comparison, 113 respondents or $31.6 \%$ disagreed, and only 104 or $29 \%$ were not sure of the roles of corporate organizations.in informing the community on the benefits of environment laws and policy.

\section{Conclusion}

Following this study's outcome, there is the need for government to take the campaigns on environmental pollution, laws, and policies to the political ward levels. It will inspire the people to own the advocacy and become proactive in a renewed attitude towards environmental laws and policies. This conversion of existing political wards to environmental advocacy clusters at the various grassroots level can be referred to as the Back to the Roots Programme. Direct supervision and leadership of these clusters by the government at the wards and grassroots will yield more success in driving the United Nations' Sustainable Development Goals.

This study identifies what is regarded as Environmental Terrorism. The phenomenon refers to all forms of intentional abuse, exploitation, and injurious action against the land, water, and air. Primary forms of environmental terrorism include open defecation/urination, indiscriminate dumping of refuse in waterways, bush burning, deforestation, soil 
excavation, and gas flaring. Unabashed refuse dumping, for example, blocks drainages and makes the large parts of the study area prone to floods perennially. Industrial fumes and gas flaring due to the huge presence of manufacturing industries in Ota, the study location was another severe concern brought to the fore in this study. Additionally, bush burning, deforestation for housing projects, and heavy-duty constructions, excavating natural soil for mining purposes is a daily occurrence in Ota. It also explains the need for more stringent measures by the grass-root government in terms of fines and community service for culprits to ensure compliance.

Also, there is the need for more awareness of the Sustainable Development Goals (SDGs) to the public from the 1st to the 17th goal, which could be translated to local languages for broader coverage and accessibility. Notably is the need for the SDG goals to be taught at all levels, across gender and income barriers at the grassroots level. The need for a collective effort on all the stakeholders (residents, individuals, groups, organizations, governments, and NGOs) is strongly advocated for a more positive outcome and results.

\section{Acknowledgments}

We are grateful to the Covenant University Centre for Research, Innovation and Design (CUCRID) for the sponsorship of this research publication.

\section{References}

1 H. Agboola, Environmental pollution in Nigeria: Types and health consequences, (Birmingham City University, 2018)

2. M. Agboola, O. Kehinde, O. Iyiola, Public relations: Pathway for the entrepreneur to achieve an enduring client-customer relationship. Evidence from three Nigerian SMEs. J. of Bus. Adm. and Man. Sci. Res. 5, 1, 1-8 (2016)

3. L. Amodu, O. Odiboh, S. Usaini, D. Yartey, T. Ekanem, Data on security implications of the adoption of internet of things by public relations professionals, Dat. in Bri. 27, 104663, (2019)

4. R. Appannagari, Environmental pollution causes and consequences: A study, Nor. Asi. Int. Res. J. of Soc. Sci. and Hum. 3, 8, 151-161 (2017)

5. H. K. Ayuba, Environmental Science: An Introductory Text, (Apani Publications, Kaduna, 2005)

6. A. Borawska, The Role of Public Awareness Campaigns in Sustainable Development. EES. 17, 4, 865-877 (2017)

7. W. P. Cunningham, M. A. Cunningham, B.W. Saigo, Environmental Science: A Global Concern, 7th Ed, (McGraw Hill Higher Education, Boston, USA 2001)

8. T. Ekanem, O. Odiboh, R. Olatunji, L. Amodu, D. Yartey, E. Adesina, B. Adeyeye, A Case for e-Teaching and e-Learning of Destination Public Relations in Nigeria, Proceedings of the $31^{\text {st }}$ International Business Information Management Association Conference, Milan Italy, April 25 -26, (2018)

9. T. Ekanem, R. Olatunji, L. Amodu, O. Odiboh, A Study of Employees' Satisfaction with New Media Usage in Universities, Proceedings of the $35^{\text {th }}$ International Business Information Management Association Conference (35 ${ }^{\text {th }}$ IBIMA), Seville, Spain, 1-2 April (2020)

10. T. Ekanem, R. Olatunji, L. Amodu, O. Odiboh, T. Oyedepo, D. Yartey, Students' perception of corporate communication units in universities: The Nigerian 
perspectives, Proceedings of the $35^{\text {th }}$ International Business Information Management Association Conference (35 ${ }^{\text {th }}$ IBIMA), Seville, Spain, 1-2 April (2020)

11. G. U. Fayomi, O. Wusu, S. E. Mini, O. S. Fayomi, O. Kilanko, Data analysis on the level of exposure to pollutions in the industrial zone: A case study of Ewekoro and Ota Township, Dat. in Bri. 19, 859-864 (2018)

12. T. O. George, Women, Environment and Food Production, Paper presented at the International Conference on The Nigerian State, Oil Industry, and the Niger Delta in Collaboration with the Centre for Applied Environmental Research, University of Missouri-Kansas City, The United States of America. Published Conference proceedings on the Niger Delta Pp. 475-482. ISBN: 978-078-435-7, (2008)

13. A. O. Igbinoba, E. O. Soola, O. Omojola, O. Adekeye, O. P. Salau, Women's mass media exposure and maternal health awareness in Ota, Nigeria, Cog. Soc. Sci. 6, 1, 1766260, (2020)

14. S. Ladan, The environment and environmental law in Nigeria, Env. Wat. J. 7, 1, 234242 (2007)

15. S. W. Littlejohn, K. A Foss, Encyclopaedia of communication theory, (Thousand Oaks, California: Sage Publications, Inc., 2009)

16. K. J. Milan, D. Tanaya, Visual pollution can have a serious degrading effect on urban and suburban Community: A study in few Places of Bengal, India, with special, Euro. Sci. J. 1857- 7431, (2015)

17. K. J. Miner, I. T. Rampedi, A. P. Ifegbesan, F. Machete, Survey on Household Awareness and Willingness to Participate in E-Waste Management in Jos, Plateau State, Nigeria, Sus. 12, 3, 1-16 (2020)

18. O. A. Moronkola, Pollution: Types, Health Consequences and Prevention. Essays on Issues in Health. (Royal People Ltd: University of Ibadan, Ibadan, 2003).

19. NESREA, National Policy on Environment (2017) https://www.nesrea.gov.ng/wpcontent/uploads/2017/09/National-Policy-on-environment.pdf

20. O. O. Odiboh, Marketology, The Philosophy of Marketing Communication for Students, Teachers and Professional, (Ilishan-Remo, Nigeria : Babcock University Press, 2020)

21 F. O. Olokoyo, T. O. George, U. I. Efobi, I. Beecroft, Land Deals and Sustainable Income: The Case of a Rural Community in Ogun State, Nigeria, Handbook of Research on In-Country Determinants and Implications with Foreign Land Acquisitions, edited by Evans Osabuohien ISBN 9781-4666740459, (IGI Global, Germany, 2014)

22. D. Olukanni, D. Azuh, T. O. George, M. P. Ajayi, The Relevance of Policy and Practice on Sanitation effort in Developing Nations: The experience of a Semi-Urban City in South-west, Nigeria ICERI Conference Proceedings, Madrid, Spain (2014)

23. Y. Omorogbe, Oil and Gas Laws in Nigeria, Simplified series, (Malthouse Press Limited, Lagos, 2001)

24. O. Oyero, K. Oyesomi, T. Abioye, E. Ajiboye, T, Kayode-Adedeji, Strategic communication for climate change awareness and behavioural change in AdoOdo/Ota local government of Ogun state. Etude la Pop. Afr. 32, 1, 4057-4067 (2018) https://doi.org/10.11564/32-1-1177

25. E. Sesen, Public Relations in Environmental Education : An Example Practice from Turkey J. of Soc. Sci. Stud. 2, 2, 134 (2015) https://doi.org/10.5296/jsss.v2i2.7392. 
26. C. Tina, Public Relations as a Measure of Checking Environmental Pollution in Nigeria, Int. J. of Eco. Comm. and Man. UK. III, 7, 668-680 (2015)

27. A. Uchegbu, A legal framework for environmental protection and enforcement. In Sada, P. O. and Odemerho, T. O. (eds) Env. Issu. and Man. in Nig. Dev. (Evans Brothers Limited, Ibadan, 1988)

28. D. E. Ufua, O. P. Salau, J. A. Dada, M. O. Adeyeye, Application of systems approach to achieving a cleaner and sustainable environment: A study of waste dumping issue on Idiroko Road, Ota, Ogun State, Nigeria, Int. J. of Env. Sc. and Tec. 17, 5, 28352844 (2020)

29. United Nations Environment Programmes, Sustainable Development Goals as they relate to environmental issues (2019) https://www.unenvironment.org/

30. United Nations Environment Report, United Nations Environment Annual Report 31. National Population Commission of Nigeria, (2020) https://www.nationalpopulation.gov.ng/

32. National Bureau of Statistics (2020) www.nigerianstat.gov.ng (2019) https://www.unenvironment.org/annualreport/2019/index.php 